\title{
COVID-19 Regulations, Political Institutions, and the Environment
}

\author{
Per G. Fredriksson ${ }^{1}$ D . Aatishya Mohanty ${ }^{2}$ \\ Accepted: 1 November 2021 / Published online: 25 November 2021 \\ (c) The Author(s), under exclusive licence to Springer Nature B.V. 2021
}

\begin{abstract}
The COVID-19 pandemic was associated with short-term air quality improvements in many countries around the world. We study whether the degree of democracy and political institutions played a role. We provide novel empirical evidence from 119 countries. A given stringency of COVID-19 containment and closure policies had a stronger effect on air quality in more democratic countries, and in countries with majoritarian rather than proportional electoral rules. Our estimates suggest that the improvement in air quality was around $57 \%$ greater in majoritarian systems than in proportional systems. Confidence in government, trust in politicians, and social capital also affected outcomes.
\end{abstract}

Keywords COVID-19 · Infectious disease · Democracy · Electoral system · Institutions · Confidence in government $\cdot$ Trust $\cdot$ Social capital $\cdot$ Rally effect

JEL Classification Q53 · I18 · H11

\section{Introduction}

The COVID-19 outbreak was declared a global pandemic by the WHO on March 11, 2020. Government responses resulted in lockdowns and mobility restrictions, which led to shortterm reductions in air pollution. In this paper, we study the role of democracy and electoral rules for the short-term improvements in air quality resulting from COVID-19 policies. To the best of our knowledge, this is a novel contribution to the literature.

The literature provides estimates of the changes in air quality resulting from the COVID-19 pandemic. Brodeur et al. (2021) find that particulate matter concentration levels declined by approximately $25 \%$ in the US and Europe. Sharma et al. (2020) report decreases of $\mathrm{PM}_{2.5}, \mathrm{PM}_{10}, \mathrm{CO}_{2}$, and $\mathrm{NO}_{2}$ of between 10 to $43 \%$ in Indian cities, and $\mathrm{Li}$

Per G. Fredriksson

per.fredriksson@louisville.edu

Aatishya Mohanty

aatishya002@e.ntu.edu.sg

1 Department of Economics, University of Louisville, Louisville, KY 40292, USA

2 Department of Economics, School of Social Sciences, Nanyang Technological University, 48 Nanyang Avenue, Singapore 639818, Singapore 
et al. (2020) and Liu (2020) report similar declines in China. In contrast, Dang and Trinh (2021) report that across 164 countries, $\mathrm{NO}_{2}$ and $\mathrm{PM}_{2.5}$ levels fell by only 5 percent and 4 percent, respectively, and that mobility restrictions explain these findings. Meanwhile, the political science, psychology and medical literatures argue that a population's response to a crisis such as the pandemic depends on citizens' trust in government, political institutions, and science (Woelfert and Kunst 2020; Schraff 2021; Esaiasson et al. 2021; Groeniger et al. 2021). Consistent with this view, trust in institutions and government affected adherence to social distancing policies during the Ebola outbreak in Liberia, e.g. (Blair et al. 2017). We test the hypothesis that changes in air pollution resulting from government COVID-19 restrictions depended on the level of democracy and democracies' electoral system. In particular, we focus on proportional and majoritarian electoral systems. We thus help fine-tune our understanding of the short-term impacts on air pollution, a research focus emphasized by, e.g., Helm (2020) and Lee (2021).

If citizens' political trust is higher in democratic governments, compliance with regulations, changes in mobility patterns, and associated pollution reductions should be higher (Marien and Hooghe 2011; Eichengreen et al. 2021). However, the system for selection of government may matter in democracies. In proportional electoral systems, government leadership tends to be more fractionalized than in majoritarian electoral systems. The political and scientific views are likely to differ, resulting in more inconsistent messaging provided by coalition governments (Sagarzazu and Kluver 2017). Differentiated communication and political infighting among government parties are likely to reduce political trust in government in proportional systems. In majoritarian systems, messaging and management during a crisis may be expected to be more in unison and clear, resulting in greater political trust and compliance. ${ }^{1}$ These differences may be particularly acute during a crisis such as a pandemic. A crisis may also give rise to "rally-around-the-flag" effects where the government is trusted to a greater degree (Dinesen and Jaeger 2013; Esaiasson et al. 2020; Schraff 2021; Groeniger et al. 2021). Flückiger et al. (2019) show that during the West African Ebola epidemic, trust in government increased with exposure to the epidemic. Using survey data from seven Western European countries, Bol et al. (2021) estimate that lockdowns increased satisfaction with democracy and trust in government by around 2.4-3.2\%, and intentions to vote for the party of the head of government rose by $4.1-4.3 \%$ (with a total increase of $6 \%$ for all governing political parties). However, the 2008 global financial crisis reduced trust in governments according to Earle (2009). Similarly, Skali et al. (2021) find that when Switzerland (with a proportional electoral system) faced crisis during war time, trust in the government declined.

Our empirical work helps shed light on whether rally-around-the-flag effects differ across proportional and majoritarian systems, with consequent differential effects on environmental quality. We provide random effects estimates using panel data from a total of 119 countries. As a measure of air quality, we utilize daily values of satellite-based aerosol optical depth (AOD) from NASA (Platnick et al. 2015) for the period January 3-June 30, 2020. To estimate the change in AOD, the median value of AOD on the same day of the week (e.g., Monday) from January 3-February 6, 2020, is used as the baseline. The regulatory measure is the COVID-19 Stringency Policy Index by Hale et al. (2020) and Polity V is our main democracy measure (Marshall and Jaggers 2018).

\footnotetext{
1 One exception is the US, where a high degree of partisanship contributed to reduced compliance with COVID-19 regulations (see, e.g., Clinton et al. 2021).
} 
The estimations suggest that a given increase in the stringency of COVID-19 policies on average reduced daily AOD levels, but the decline was greater in more democratic countries. Within the group of democracies, the marginal AOD reductions were smaller in countries with proportional electoral rules compared to those with majoritarian systems. To help explain these findings, we show differential responses in community mobility. Mobility changes were measured at transit stations, groceries and pharmacies, and workplaces (data provided by Google 2020).

Next, we control for pre-COVID-19 (baseline) levels of confidence in government, trust in politicians, and social capital. Our results for democracies, proportional and majoritarian systems remain robust overall. COVID-19 policies reduced both AOD and mobility by more in countries with greater confidence in government and trust in politicians. Thus, there were rally-around-the-flag effects in countries with these characteristics. However, although social capital reinforced a decline in air pollution, this was not due to the mobility changes included in the analysis. The estimations suggest that the decline in mobility was slightly lower in countries with high social capital. One potential explanation may be that populations in countries with high social capital believed that others within their community would stay socially distant and wear masks, and they therefore would not need to comply and reduce their own mobility to the same degree. Moreover, Woelfert and Kunst (2020) report that social trust was related to a higher growth rate of infections in a study of 65 countries. It appears that in countries with high social capital the decline in air quality occurred to a higher degree via other channels such as declines in industrial production, construction, and long-range transportation ( $\mathrm{Li}$ et al. 2020). However, the mobility changes help explain the overall impacts of COVID-19 regulations on air quality in democracies, and in proportional and majoritarian systems.

Our results are robust to controlling for risk exposure, the capacity of the health care sector, legal origins, colonial history, and institutional quality. While the literature has previously discussed the relationship between democracy, political institutions, and environmental quality and policy (e.g., Folke 2014; Kammerlander and Schulze 2020; Ang and Fredriksson 2021; Hu and Chen 2021), to our knowledge the questions addressed in the present paper are novel. We believe our findings broaden our understanding of the environmental (and health) effects of government policymaking, in particular during a crisis situation.

The paper is organized as follows. Section 2 discusses the empirical specification and data, and Sect. 3 reports the baseline results. Section 4 introduces measures of government confidence, trust and social capital into the baseline models. Section 5 shows how changes in mobility, conditional on democratic institutions, help explain the changes in pollution. Section 6 reports robustness analysis based on potential vulnerabilities, institutions, demography, instrumental variables, and excluding regions, respectively. Section 7 concludes.

\section{Empirical Specification and Data}

The following random-effects panel data model is estimated:

$$
\begin{aligned}
\text { AOD }_{i, t}=\alpha & +\beta \text { Stringency }_{i, t-1}+\gamma \text { Stringency }_{i, t-1} \times \text { Electoralrules }_{i} \\
& + \text { SStringenc }_{i, t-1} \times \text { Democracy }_{i}+c v_{i}^{\prime} \eta+\theta_{i}+\sigma_{t}+\varepsilon_{i, t}
\end{aligned}
$$

$A O D$ is an index of aerosol optical depth in country $i$ on day $t$, Stringency (lagged one day) is a measure of the rigor of government-imposed policies, Electoral rules is a dummy 
variable representing proportional or majoritarian electoral system, Democracy is a measure of the degree of democracy, and $c v^{\prime}$ is a set of control variables which are included both individually and also interacted with Stringency. $\theta_{i}$ captures the random disturbance of the $i$ th country, which is constant over time and independent across countries. The specification also allows for time fixed effects, $\sigma_{t} . \varepsilon_{i, t}$ is the idiosyncratic error term. ${ }^{2}$

Daily values of satellite-based aerosol optical depth (AOD) from NASA (Platnick et al. 2015) measure air quality within the period January 3-June 30, 2020. AOD measures the degree to which the dispersion of the solar beam is hindered due to the presence of pollution particles (dust, haze) in the atmosphere (NOAA 2020). Data are drawn from the moderate resolution imaging spectroradiometer (MODIS) aboard NASA's Terra satellite. An AOD value of 0.01 indicates a clean and clear sky, 0.5 is hazy, and values of 1-3 or greater correspond to highly polluted air. For instance, on 11th February 2020, Norway had an average AOD value of 0.05, Bangladesh was at 0.6, while Ghana recorded an average AOD value of 2.5. We construct the AOD variable by measuring the change in AOD on a day relative to baseline days, where a baseline day is the median value of AOD on the same day of the week (e.g., Monday) from January 3-February 6, 2020. A negative AOD value indicates a decrease in pollution relative to the baseline period, while a positive value reflects an increase in pollution. The baseline period is selected such that few countries had taken strong action yet. The subsequent study period, February 7-June 30, 2020, is chosen mainly due to data availability, but has the advantage that major investments or changes in trade and demand patterns are less likely to strongly influence our results.

AOD provides an indirect but precise proxy of air quality. While PM 2.5, $\mathrm{NO}_{2}$ and $\mathrm{CO}_{2}$ are common measures of air pollution in the literature, we use AOD data due to its wide geographic and temporal coverage. Multiple previous studies have relied on AOD data as a measure of air quality, and also demonstrated a positive correlation between AOD, PM2.5 and PM10 (see, e.g., Hutchison 2003; Engel-Cox et al. 2004; Hu and Rao 2009; Gutierrez 2010; Khoshsima et al. 2014, Kong et al. 2016). Using AOD data has advantages in comparison to the sparse coverage by other air quality measures. For example, AOD appears preferable to PM2.5, which is dependent upon the availability of ground-level air quality monitoring stations; their coverage differ across regions depending on geographic and economic factors (Shi et al. 2018). Furthermore, since aerosols are also known to disrupt atmospheric stability and hydrological cycles, it provides us with added information on air quality (Li et al. 2007; IPCC, 2013). Figure 1 shows the spatial distribution of AOD across countries.

We use the COVID-19 Stringency Policy Index by Hale et al. (2020), which measures regulations including school closings, workplace closings, cancellation of public events, restrictions on gatherings, closure of public transport, stay at home requirements, restrictions on internal movement, international travel controls, and provision of public information campaigns. For example, the raw sub-index for school closings ranges between 0 and 3:0 (no measures); 1 (recommended closing); 2 (required closing, but only for some school types or age groups, e.g., just high schools or just public

\footnotetext{
${ }^{2}$ We use standard errors for generalized least square estimates. Abadie et al. (2017) argue that the decision to use clustered standard errors depends on the sampling design. Clustered standard errors should be utilized if the analysis contains a small sample from a larger population and the sampling varies systematically with groups in the sample. In this paper, we use a global cross-country analysis. This ensures that all clusters in the population of interest are sufficiently represented in the sample. Thus, we do not use clustered standard errors.
} 


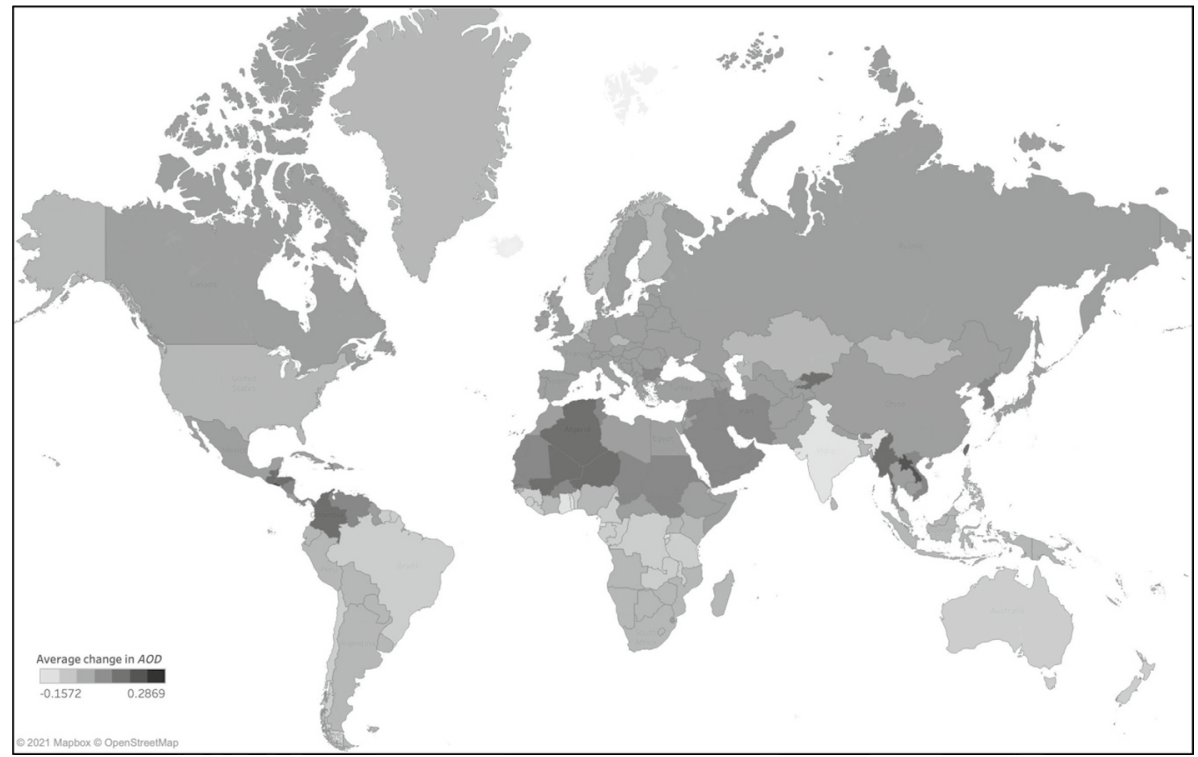

Fig. 1 Distribution of the average change in $A O D$ across countries Notes: The figure shows the spatial variation in the average change in AOD from the base period January 3-February 6, 2020, to February 7-June 30,2020 , for 119 countries

schools); 3 (required closing of all levels). The sub-index for closure of public transport may take three different values: 0 (no measures); 1 (recommended closing, or significantly reduce volume/route/means of transport available); 2 (required closing, or prohibit most citizens from using public transport). Moreover, the value for each measure is interacted with an indicator variable which takes a value of zero if the measure is targeted only locally, and unity if the policy applies generally. The daily variable is constructed by measuring the change in Stringency relative to the baseline day, the median value on the same day of the week January 3-February 6, 2020. The index is then rescaled from 0 to 1 . A positive value of Stringency indicates an increase in the stringency of policies relative to the baseline period. Figure 2 shows the spatial distribution of Stringency across countries. The mean of Stringency is 0.44 and 0.45 in democracies and autocracies, respectively.

IDEA (2018) provides data on electoral systems; Marshall and Jaggers (2018) provide the Polity V democracy measure. We rescaled the original Polity V scale from -10 to 10 , to 0 to 10 , where a higher value reflects a stronger democracy. We define autocracies as countries with a score in the 0 to 2 range, and democracies as those with a score above 2 . We have data on 49 proportional system democracies, 24 majoritarian system democracies, 6 proportional system autocracies, and 13 majoritarian system autocracies (IDEA 2018). We also have 20 democracies (e.g., Germany, Italy, Japan and South Korea) and 7 autocracies that are neither proportional nor majoritarian systems.

The control variables are the share of the manufacturing sector in GDP, vehicles/1000 inhabitants, climate change policy stringency, KOF globalization index, GDP/capita. These variables control for the level of pollution related to polluting production and consumption, transportation, environmental regulations, and trade patterns (Shapiro and Walker 2018; Wang 2021). The controls are entered individually and as Stringency interactions. 


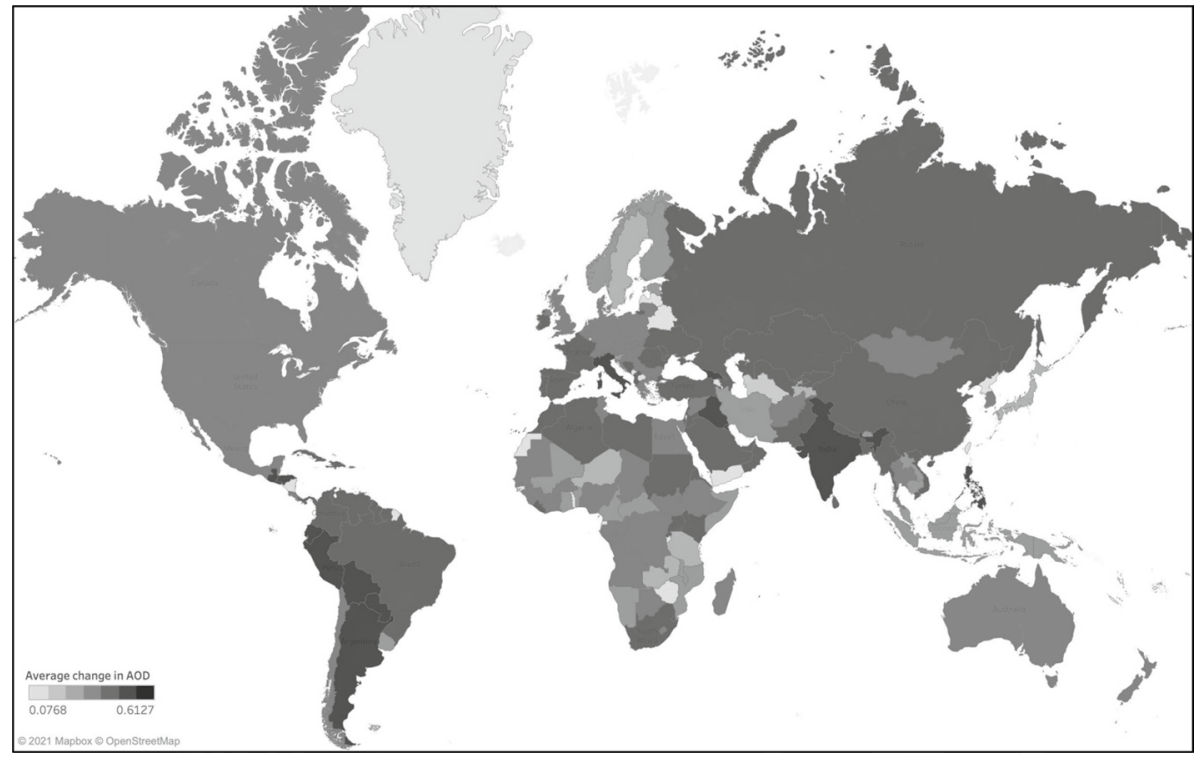

Fig. 2 Distribution of the average change in Stringency across countries Notes: The figure shows the spatial variation in the average change in Stringency from the base period January 3-February 6, 2020, to February 7-June 30, 2020, for 119 countries

Tables 9, 10, 11 in the Appendix provide definitions, sources, and summary statistics for all variables.

\section{Baseline Results}

Columns (1)-(3) in Table 1 provide baseline estimates of the effect of Stringency on AOD, including the interactions with Democracy, Proportional, and Majoritarian. The sample includes all autocracies. The marginal effect of Stringency is reported in each column. Column (1) suggests that Stringency has a negative effect on AOD, and the effect is stronger the higher the level of Democracy. Next, the effect of Stringency is smaller in proportional systems than in majoritarian systems. The estimate in column (2) suggests that (taking all interactions between control variables and Stringency into account) the estimated marginal effect of one standard deviation change in Stringency equals - 0.111 in proportional systems, while column (3) indicates that this effect equals -0.174 in majoritarian systems (evaluated at the mean of all variables). Thus, the marginal change in AOD is $57 \%$ greater in majoritarian systems, where the negative effect equals 0.83 of a standard deviation. Columns (4)-(6) use an alternative Democracy measure, created by principal component analysis of four different democracy measures (Polity V; Vanhanen 2019; EIU 2018; Freedom House 2018). The results remain robust. ${ }^{3}$

\footnotetext{
3 The results remain robust when using these democracy indices individually (results available upon request). Note also that Vanhanen (2019) lacks data on Afghanistan and Ireland, reducing the number of observations in the principal component analysis.
} 


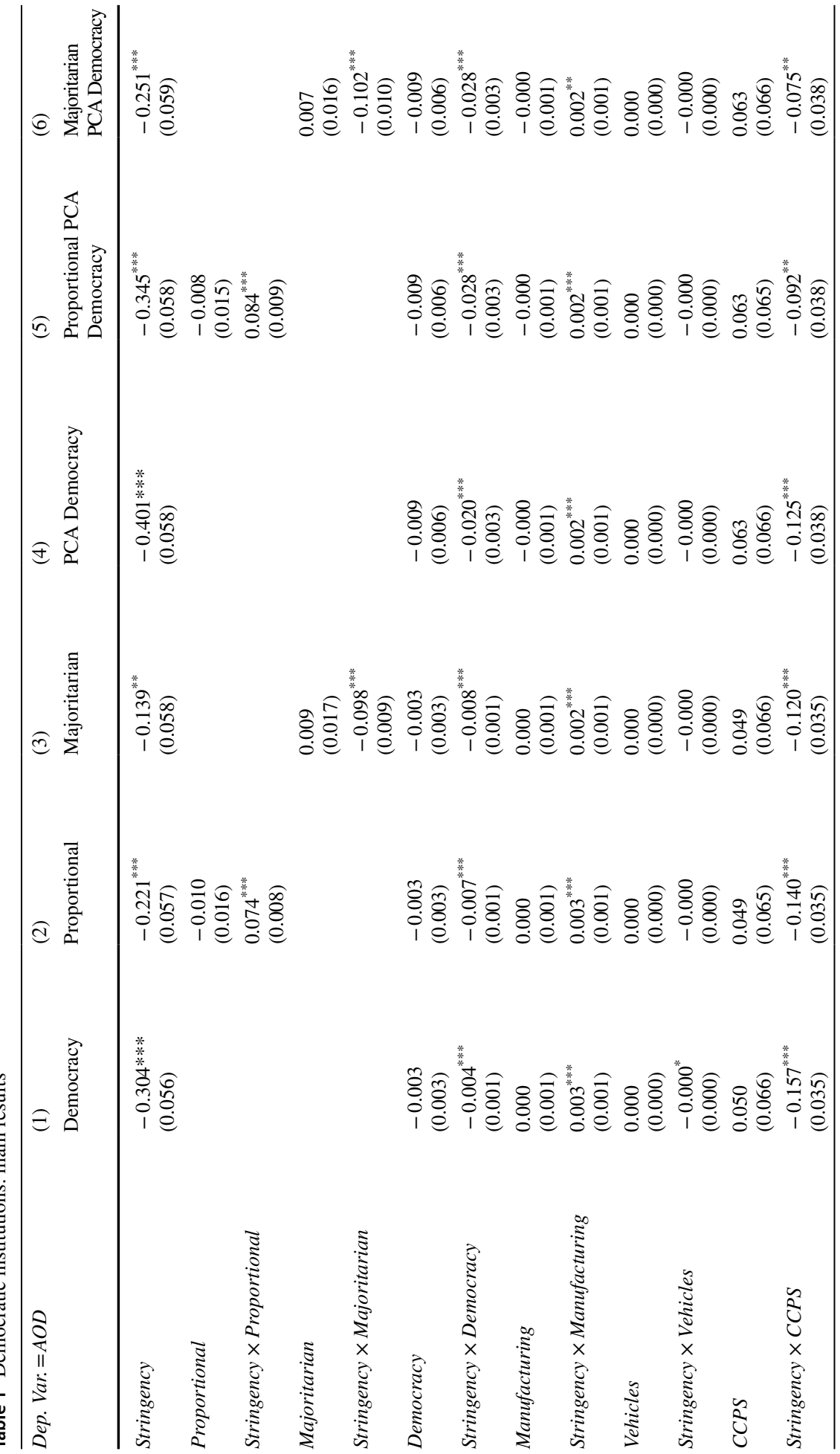




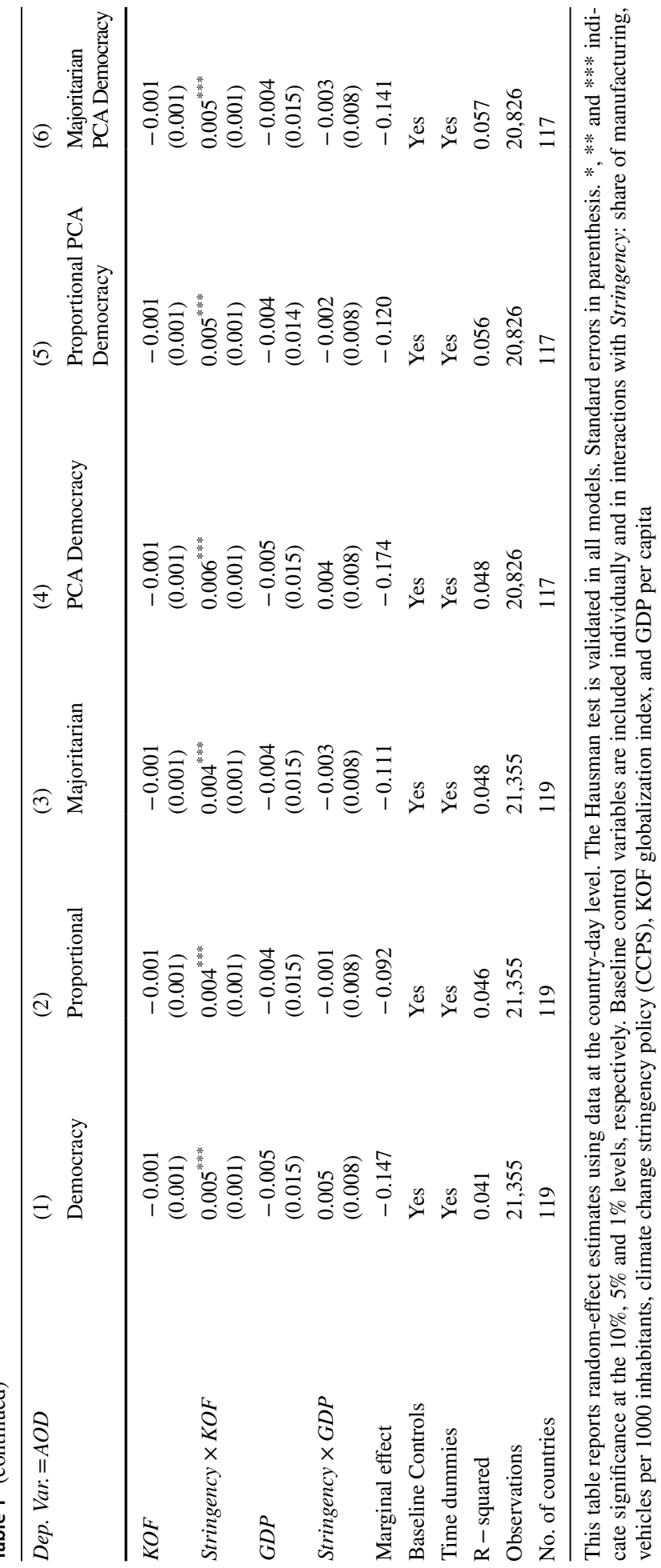




\section{Confidence, Trust and Social Capital}

Marien and Hooghe (2011) report that lower levels of political trust are associated with lower compliance with the law. The general population's response to the pandemic depends on their trust in government, political institutions, and science (Esaiasson et al. 2021; Schraff, 2021; Woelfert and Kunst, 2020; Groeniger et al. 2021). However, the level of trust may change as a result of the pandemic (Bol et al. 2021; Skali et al. 2021). Here we study whether a given stringency of COVID-19 policies have differential effects on pollution, conditional on pre-pandemic levels of trust. We also study whether the effect of stringency depends on several forms of trust, yielding rally-around-the-flag effects.

Table 2 includes measures of the degree of confidence in government and the level of trust in politicians. Government Confidence (columns (1)-(3)) and Trust in Politicians (columns (4)-(6)) are the national averages of individual WVS (2015) and World Economic Forum (2017) survey responses, respectively. In columns (7)-(9), we utilize Social Capital from the World Economic Forum (2018), which measures trust among the general public and society overall. It may provide a partial or indirect measure of trust in government. These three baseline measures were created before the COVID-19 pandemic. Including these in the analysis helps us detect if rally-around-the-flag effects depended on preexisting trust. Moreover, we are more likely to be able to discern differences in behavioral responses to changes in Stringency between proportional versus majoritarian systems, since the Stringency measure applies exclusively to the COVID-19 pandemic.

According to all columns in Table 2, the effect of Stringency on AOD is greater in democracies. Moreover, accounting for confidence in government and trust in politicians, the differential effect across proportional and majoritarian systems of Stringency remains. For example, according to column (2), at the mean values of Confidence in Government and Democracy (including the insignificant direct effect of Stringency), the estimated marginal effect of one standard deviation change in Stringency equals -0.127 in proportional systems. According to column (3), in majoritarian systems the marginal effect equals -0.141 (including the insignificant direct effect of Stringency). Thus, the marginal change is $11 \%$ greater in majoritarian systems. ${ }^{4}$ Moreover, Stringency has a more negative effect on AOD the greater the level of Government Confidence, Trust in Politicians, and Social Capital. This indicates rally-around-the-flag effects.

\section{Mobility Changes}

In this section, we study whether changes in mobility help explain the estimated effects. To measure the effect of Stringency on mobility, we use data on mobility trends from the Google Community Mobility Reports (Google 2020). Mobility reductions are measured at transit stations, groceries and pharmacies, and workplaces. The change in the daily movement in each of these areas is compared to the baseline day, defined as the median value of movement in an area on the same day of the week during the time period January 3-February 6,2020 .

\footnotetext{
4 To the best of our knowledge, the literature appears not to have addressed how to determine statistically significant differences in cases with multiple interaction terms and panel data.
} 


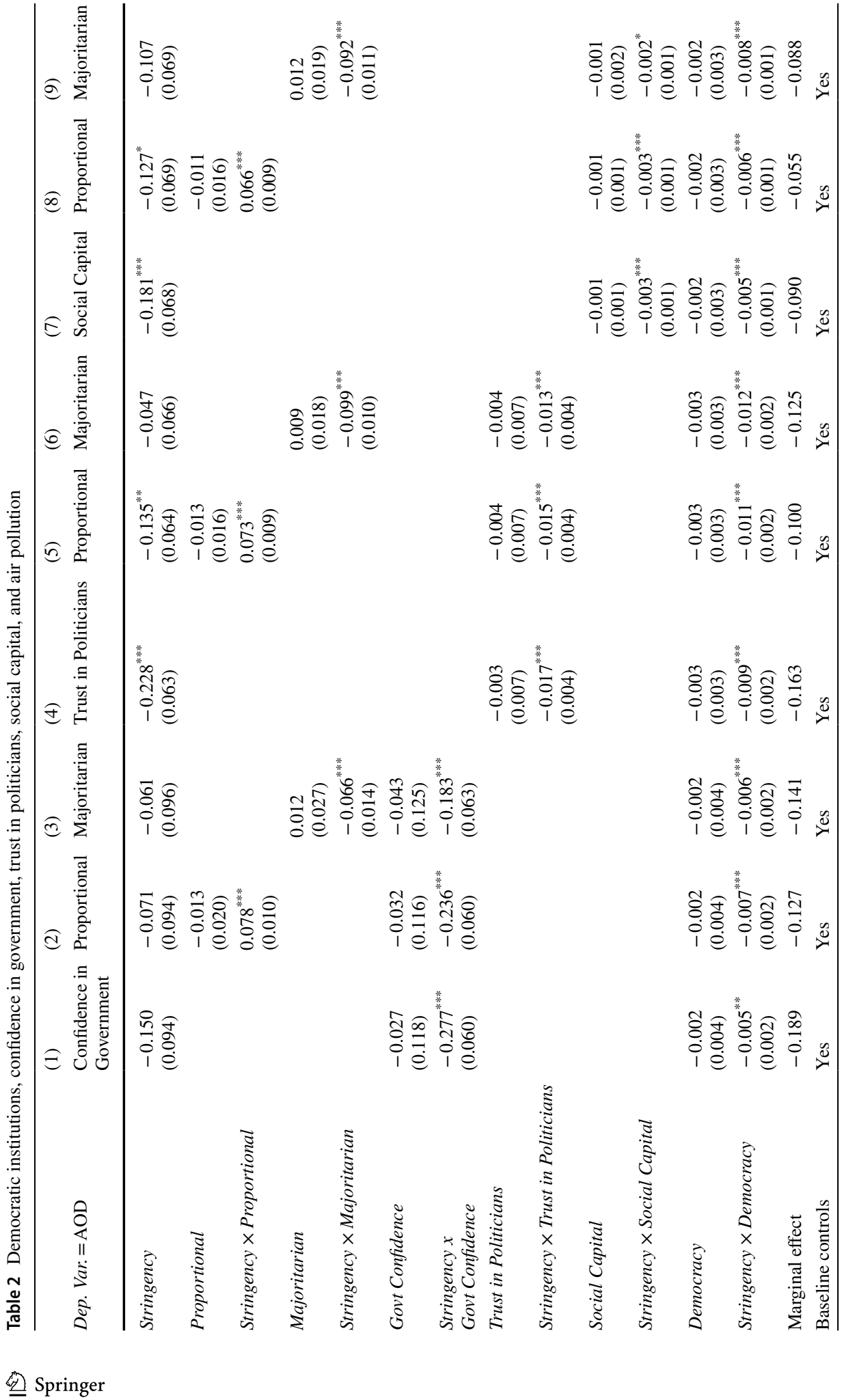




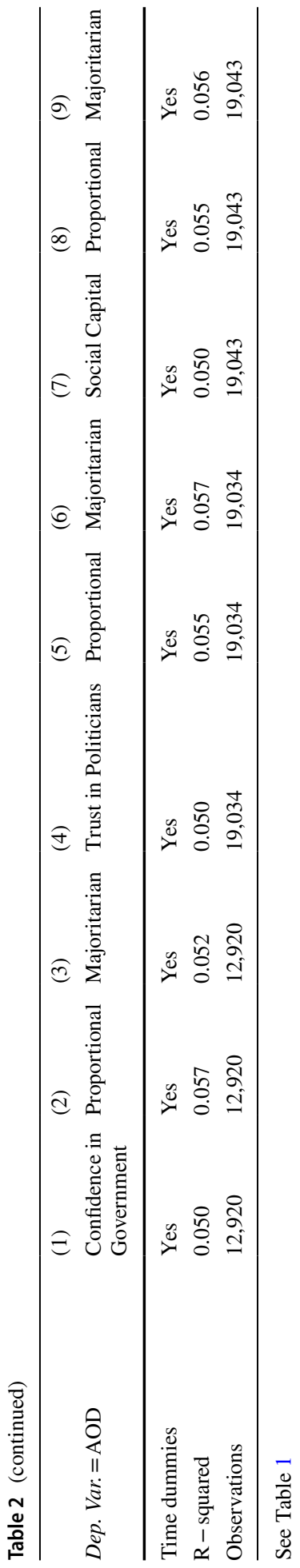




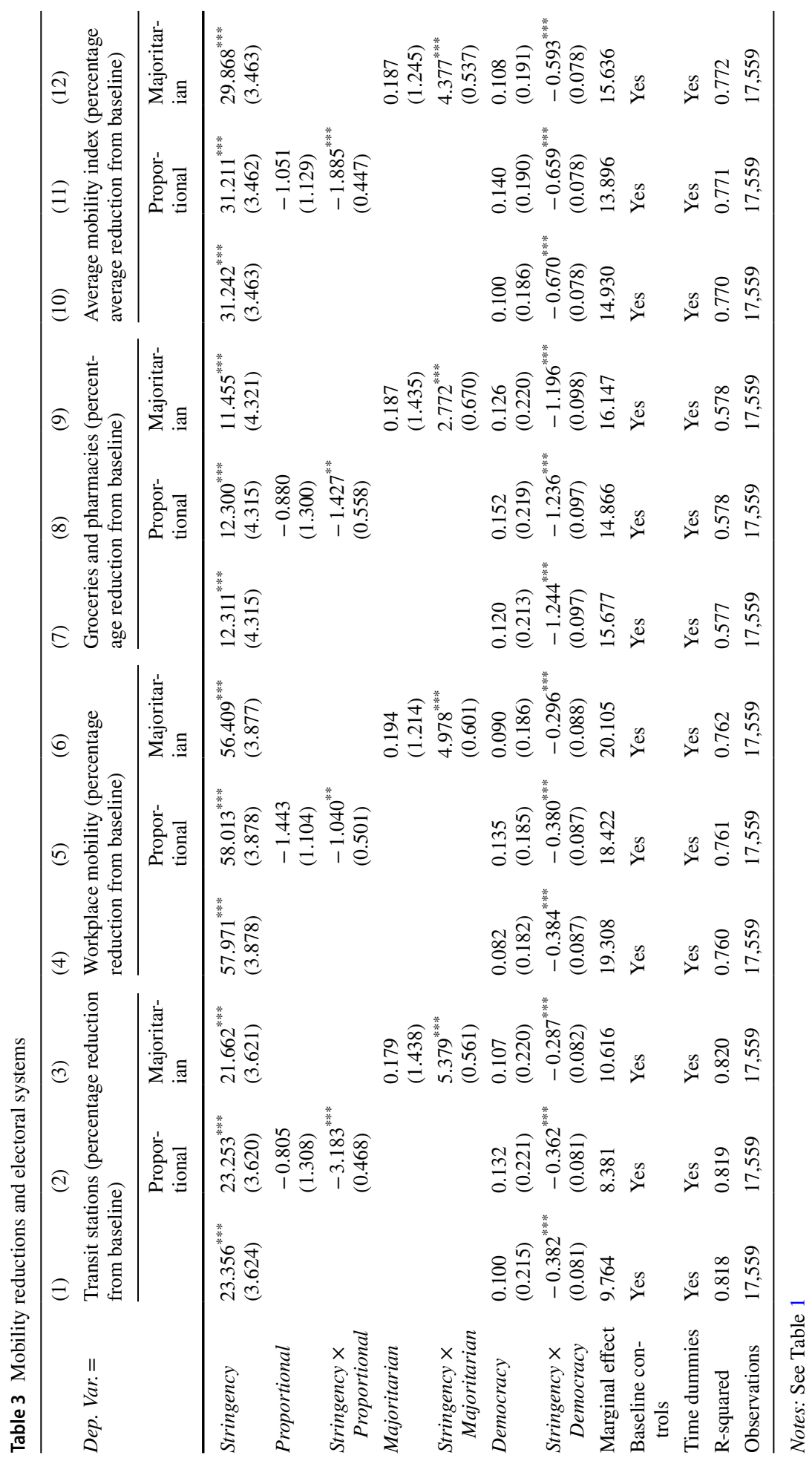


Columns (1)-(3) in Table 3 use the percentage reduction in mobility at transit stations as a dependent variable, columns (4)-(6) use the percentage reduction in workplace mobility, and columns (7)-(9) employ the percentage reduction in mobility in groceries and pharmacies. Columns (10)-(12) use an average of the mobility changes in columns (1)-(9). The marginal effects of Stringency are calculated taking all interactions into account (not all coefficients reported).

All columns in Table 3 suggest that the marginal effect of Stringency on mobility reductions is lower in more democratic countries. Thus, the greater effects of Stringency on air pollution in democracies found in Tables 1 and 2 are not due to mobility changes of the forms studied here. The greater civil liberties enjoyed in democracies may have resulted in a lower level of compliance with mobility restrictions. The stringency measures implemented in democracies may also have had a different focus or been enforced less strictly, therefore having a relatively smaller effect on mobility. Moreover, we may have incomplete data on mobility reductions. For example, emissions from international air travel and the manufacturing sector may have fallen more in democracies. Saha et al. (2017) find that the level of civil liberties was positively correlated with inbound tourism in 110 countries during 1995-2012. A sharper decline in tourism and international travel in democracies may help explain our findings. In addition, Acemoglu et al. (2019) find that democracy has a positive effect on per capita GDP and capital investments. The marginal effect of COVID19 restriction on economic activity and pollution may therefore have been relatively larger. Note also that relative to the direct effect of Stringency, the effect of democracy is quite small, except perhaps in columns (7)-(9).

Next, the differential effects in proportional and majoritarian systems are consistent with the results for AOD in Tables 1 and 2. For example, according to the estimates in column (2), the marginal reduction in mobility of a one standard deviation increase in Stringency in proportional systems equals 8.381 . This is $29.5 \%$ of a standard deviation of mobility at transit stations. Based on column (3), the corresponding effect in majoritarian systems equals 10.616 , or $37.3 \%$. The pattern is similar in columns (5)-(6), (8)-(9) and (11)-(12). Thus, the effects of more stringent COVID-19 regulations on mobility are relatively smaller in proportional systems than in majoritarian systems. This helps explain the differential effects on AOD.

Table 4 investigates the effect of stringency on mobility, taking institutions and culture into consideration. The average mobility index (from Table 3 ) is utilized in all columns. Columns (1)-(3) utilize our measure of confidence in government, columns (4)-(6) employ the measure of trust in politicians, and columns (7)-(9) include our measure of social capital. The impact of Stringency on mobility remains lower in democracies (except in columns (1)-(3) with insignificant Democracy interactions, perhaps due to a decline in observations) and proportional systems, but greater in majoritarian systems and where trust in government and government confidence are higher. ${ }^{5}$ This indicates that rally-around-theflag effects occurred in such countries. Columns (7)-(9) suggest that the marginal effect of Stringency on mobility is relatively smaller where social capital is greater. The population in these countries potentially had a harder time giving up social activities. Alternatively, they may have believed that other citizens would practice social distancing, wear protective

\footnotetext{
5 Based on WVS (2015), the average level of confidence in government in proportional systems equals 0.34 and 0.44 in majoritarian systems. According to World Economic Forum (2018) the average level of trust in politicians in proportional systems equals 0.32 , and 0.33 in majoritarian systems (higher values represent greater levels of trust).
} 


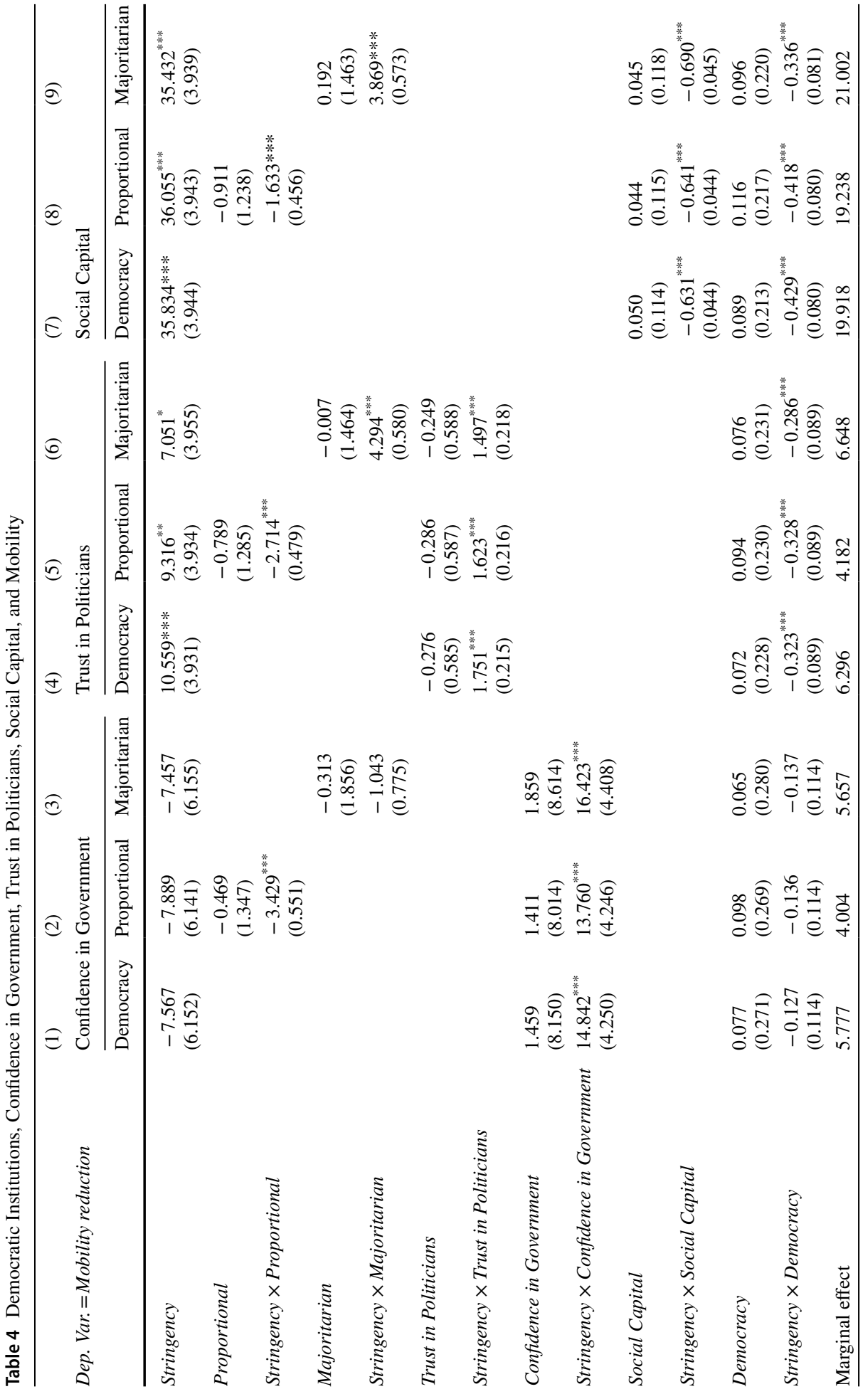




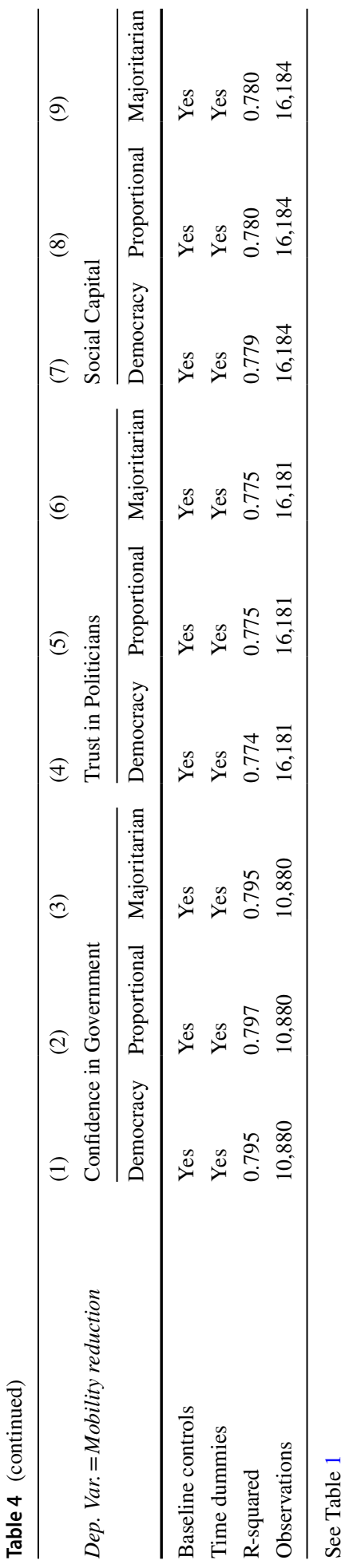


Table 5 Vulnerabilities
(1)
(2)
(3)
(4)
(5)
(6)

Dep. Var. $=$ AOD $\quad$ PCA high exposure

Health system capacity specific to COVID - 19

General health system capacity

\begin{tabular}{|c|c|c|c|c|c|c|}
\hline & & & \\
\hline & Proportional & Majoritarian & Proportional & Majoritarian & Proportional & Majoritarian \\
\hline Stringency & $\begin{array}{l}-0.221^{* * *} \\
(0.057)\end{array}$ & $\begin{array}{l}-0.139^{* *} \\
(0.058)\end{array}$ & $\begin{array}{l}-0.221^{* * * *} \\
(0.057)\end{array}$ & $\begin{array}{l}-0.139^{* *} \\
(0.058)\end{array}$ & $\begin{array}{l}-0.221^{* * * *} \\
(0.057)\end{array}$ & $\begin{array}{l}-0.139^{* *} \\
(0.058)\end{array}$ \\
\hline Proportional & $\begin{array}{l}-0.010 \\
(0.016)\end{array}$ & & $\begin{array}{l}-0.011 \\
(0.016)\end{array}$ & & $\begin{array}{l}-0.009 \\
(0.016)\end{array}$ & \\
\hline $\begin{array}{l}\text { Stringency } \times \text { Pro- } \\
\text { portional }\end{array}$ & $\begin{array}{l}0.074^{* * * *} \\
(0.008)\end{array}$ & & $\begin{array}{l}0.073^{* * *} \\
(0.008)\end{array}$ & & $\begin{array}{l}0.074^{* * *} \\
(0.008)\end{array}$ & \\
\hline PCA high exposure & $\begin{array}{l}0.003 \\
(0.008)\end{array}$ & $\begin{array}{l}0.003 \\
(0.008)\end{array}$ & & & & \\
\hline Majoritarian & & $\begin{array}{l}0.009 \\
(0.017)\end{array}$ & & $\begin{array}{l}0.010 \\
(0.017)\end{array}$ & & $\begin{array}{l}0.009 \\
(0.017)\end{array}$ \\
\hline $\begin{array}{l}\text { Stringency } \times \\
\text { Majoritarian }\end{array}$ & & $\begin{array}{l}-0.098^{* * *} \\
(0.009)\end{array}$ & & $\begin{array}{l}-0.098^{* * * *} \\
(0.009)\end{array}$ & & $\begin{array}{l}-0.098^{* * * *} \\
(0.009)\end{array}$ \\
\hline $\begin{array}{l}\text { Health capacity } \\
\text { (Covid-19) }\end{array}$ & & & $\begin{array}{l}0.005 \\
(0.005)\end{array}$ & $\begin{array}{l}0.005 \\
(0.005)\end{array}$ & & \\
\hline $\begin{array}{l}\text { Health system } \\
\text { capacity }\end{array}$ & & & & & $\begin{array}{l}-0.001 \\
(0.004)\end{array}$ & $\begin{array}{l}0.000 \\
(0.004)\end{array}$ \\
\hline Democracy & $\begin{array}{l}-0.003 \\
(0.003)\end{array}$ & $\begin{array}{l}-0.003 \\
(0.003)\end{array}$ & $\begin{array}{l}-0.003 \\
(0.003)\end{array}$ & $\begin{array}{l}-0.003 \\
(0.003)\end{array}$ & $\begin{array}{l}-0.003 \\
(0.003)\end{array}$ & $\begin{array}{l}-0.003 \\
(0.003)\end{array}$ \\
\hline $\begin{array}{l}\text { Stringency } \times \\
\text { Democracy }\end{array}$ & $\begin{array}{l}-0.007^{\text {**** }} \\
(0.001)\end{array}$ & $\begin{array}{l}-0.008^{* * *} \\
(0.001)\end{array}$ & $\begin{array}{l}-0.007^{* * * *} \\
(0.001)\end{array}$ & $\begin{array}{l}-0.008^{* * * *} \\
(0.001)\end{array}$ & $\begin{array}{l}-0.007^{* * *} \\
(0.001)\end{array}$ & $\begin{array}{l}-0.008^{* * * *} \\
(0.001)\end{array}$ \\
\hline Marginal effect & -0.090 & -0.110 & -0.086 & -0.105 & -0.092 & -0.112 \\
\hline Baseline controls & Yes & Yes & Yes & Yes & Yes & Yes \\
\hline Time dummies & Yes & Yes & Yes & Yes & Yes & Yes \\
\hline R-squared & 0.046 & 0.048 & 0.047 & 0.050 & 0.046 & 0.048 \\
\hline Observations & 21,355 & 21,355 & 21,355 & 21,355 & 21,355 & 21,355 \\
\hline
\end{tabular}

See Table 1

masks, and stay safe, and they therefore would not need to reduce their own mobility to the same extent. ${ }^{6}$ This appears consistent with Woelfert and Kunst (2020), who in a study of 65 countries find that social trust was related to a higher growth rate of infections. In these countries, the decline in air quality may to a higher degree have occurred via other channels such as declines in industrial production, construction, and long-range transportation ( $\mathrm{Li}$ et al. 2020). However, the mobility changes do help explain the overall impacts of COVID-19 regulations on air quality in democracies, and in proportional and majoritarian systems.

\footnotetext{
6 This is similar to Guglielmi et al. (2021), who argue that Italians who had a favorable appraisal of regional institutions felt safer from the virus, reducing compliance with restrictions.
} 
Table 6 Additional confounders
(1)
(2)
(3)
(4)
(5)
(6)

\begin{tabular}{lllllll} 
Dep. Var. AOD & Proportional & Majoritarian & Proportional & Majoritarian & Proportional & Majoritarian \\
\hline Stringency & $-0.239^{* * *}$ & $-0.143^{* *}$ & $-0.194^{* * *}$ & $-0.104^{*}$ & $-0.216^{* * *}$ & $-0.135^{* *}$ \\
& $(0.057)$ & $(0.059)$ & $(0.057)$ & $(0.058)$ & $(0.057)$ & $(0.058)$ \\
Proportional & -0.023 & & -0.009 & & -0.003 & \\
& $(0.017)$ & & $(0.016)$ & & $(0.017)$ & \\
Proportional $\times$ & $0.073^{* * *}$ & & $0.079^{* * *}$ & & $0.074^{* * *}$ & \\
Stringency & $(0.008)$ & & $(0.009)$ & & $(0.008)$ & \\
Majoritarian & & 0.029 & & 0.011 & & 0.013 \\
& & $(0.020)$ & & $(0.017)$ & & $(0.019)$ \\
Majoritarian $\times$ & & $-0.097^{* * *}$ & & $-0.107^{* * *}$ & & $-0.098^{* * *}$ \\
Stringency & & $(0.010)$ & & $(0.010)$ & & $(0.009)$ \\
Democracy & -0.001 & -0.001 & -0.002 & -0.002 & -0.003 & -0.003 \\
& $(0.003)$ & $(0.003)$ & $(0.003)$ & $(0.003)$ & $(0.003)$ & $(0.003)$ \\
Stringency $\times$ & $-0.007^{* * *}$ & $-0.008^{* * *}$ & $-0.007^{* * *}$ & $-0.008^{* * *}$ & $-0.007^{* * *}$ & $-0.008^{* * *}$ \\
Democracy & $(0.001)$ & $(0.001)$ & $(0.001)$ & $(0.001)$ & $(0.001)$ & $(0.001)$ \\
Marginal effect & -0.085 & -0.088 & -0.090 & -0.109 & -0.089 & -0.109 \\
Baseline controls & Yes & Yes & Yes & Yes & Yes & Yes \\
Time dummies & Yes & Yes & Yes & Yes & Yes & Yes \\
Legal Origins dum- & Yes & Yes & No & No & No & No \\
mies & & & & & & \\
Institutions & No & No & Yes & Yes & No & No \\
Colony dummies & No & No & No & No & Yes & Yes \\
R-squared & 0.056 & 0.056 & 0.049 & 0.051 & 0.067 & 0.067 \\
Observations & 21,180 & 21,180 & 20,815 & 20,815 & 21,177 & 21,177 \\
\hline See & & & & & & \\
\hline
\end{tabular}

See Table 1

\section{Robustness Analysis}

\subsection{Vulnerabilities}

In this section, we control for vulnerabilities that may affect behavior and thus the effect of regulations on pollution during the pandemic. Columns (1)-(2) in Table 5 control for risk exposure. This is the first principal component of three measures that reflect risk exposure: population density, net migration and urbanization (see, e.g., Noy et al. 2020). In columns (3)-(4) we control for the health system capacity specific to COVID-19 and in columns (5)-(6) for country-level health system capacity in general. In all cases, the results are consistent with our baseline findings.

\subsection{Institutions}

The efficacy of government interventions can vary greatly based on legal origin, institutional quality and colonial origin (Fredriksson and Wollscheid 2015; La Porta et al. 2018; Ang and Fredriksson 2021). We control for these factors in Table 6. The results remain robust. The marginal effect of Stringency on AOD is stronger the greater is Democracy and in majoritarian systems. The marginal effect is relatively weaker in proportional systems. 


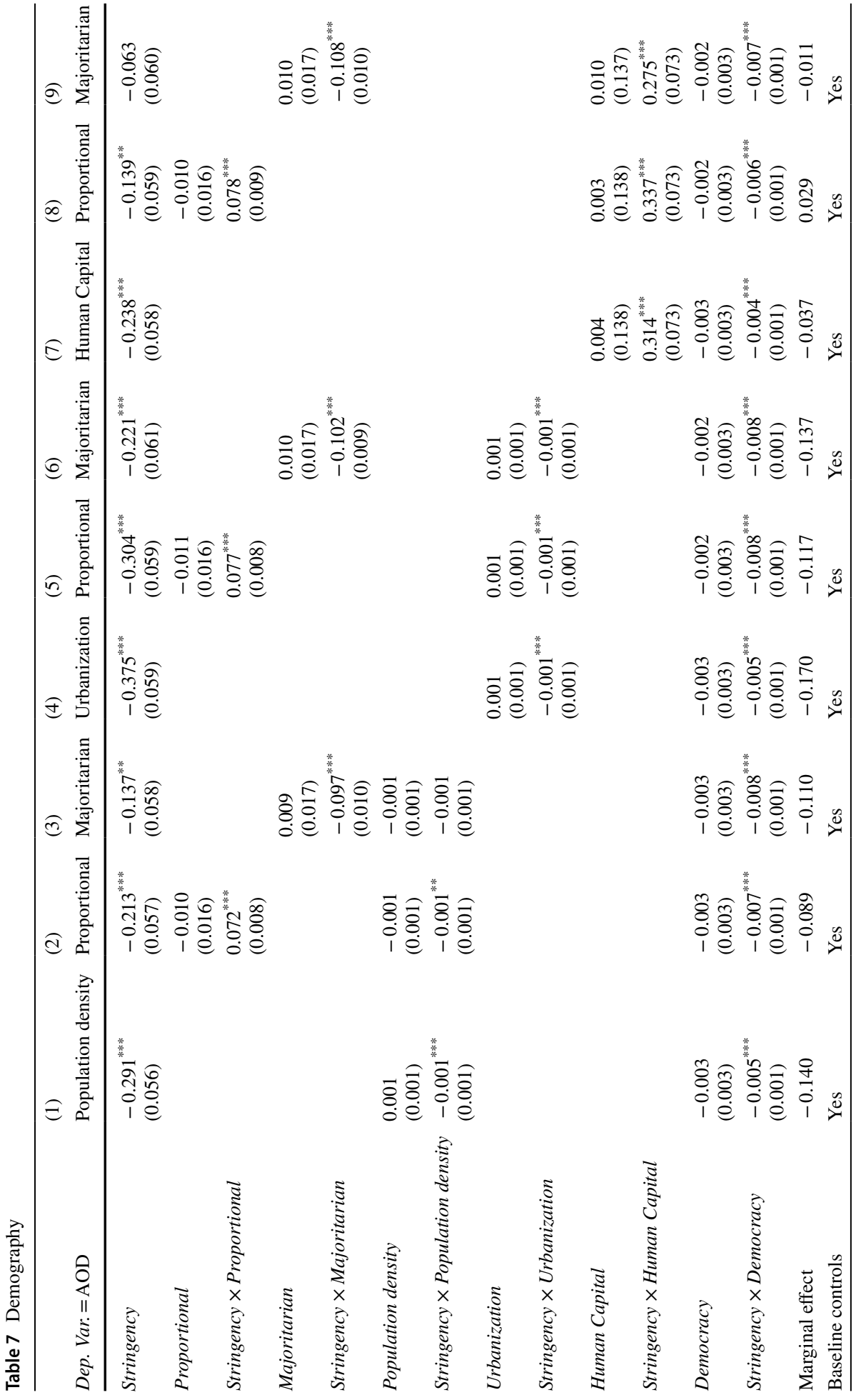




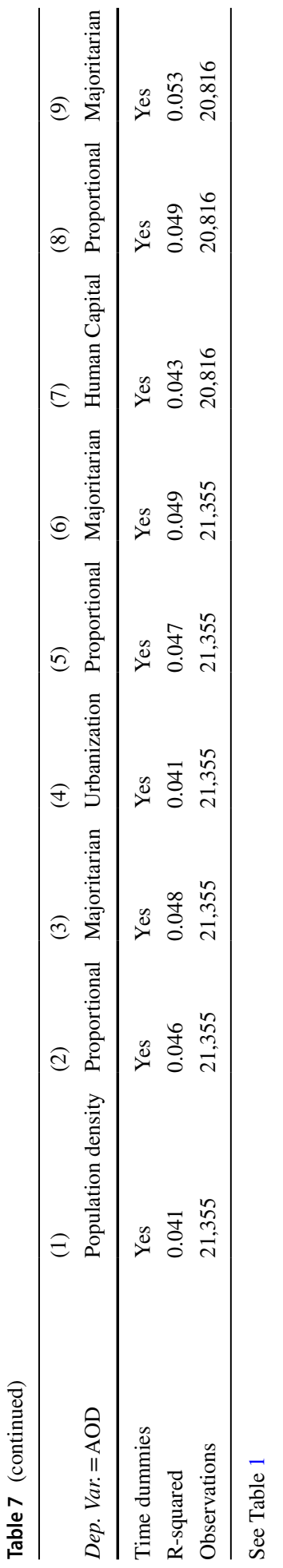




\subsection{Demography}

Next, we look at demographic variables that may affect stringency during the pandemic: population density, urbanization and human capital. Table 7 shows that in all cases the baseline results remain robust to the addition of the demographic confounders.

\subsection{Instrumental Variable Estimates}

In this section, we provide instrumental variable estimates to mitigate concerns about endogeneity. First, we use the daily cumulative number of COVID-19 cases as an instrument for Stringency. This is a suitable instrument as stringency regulations were progressively raised with increases in COVID-19 cases. However, the cumulative number of cases is also unlikely to directly lead to AOD changes, and this IV is therefore likely to satisfying the exclusion restriction. All control variables interacted with Stringency are also instrumented. The IV-2SLS results are reported in panel (a) in Table 8. Columns (1)-(2) use the cumulative number of COVID-19 cases lagged by one day, and columns (3)-(4) lag the instrument by five days. The lags account for the time it takes to implement and make social mobility restrictions effective. The results are largely consistent with the main findings.

Second, we utilize a measure of the potential increase in crop yield due to irrigation in agriculture (irrigation potential) as an instrument to exploit the exogeneous variation of democracy. Bentzen et al. (2017) compile this measure of irrigation potential based on data from the Food and Agriculture Organization's (FAO) global Agro-Ecological Zones (GAEZ) 2002 database. Bentzen et al. (2017) find that countries with greater irrigation potential are less democratic in the present day. The IV-2SLS results reported in panel (b) of the Table 8 remain robust.

Using the critical values provided by Stock and Yogo (2005), the Cragg and Donald (1993) weak identification test rejects the null that the instruments are only weakly correlated with the endogenous regressors. The Anderson-Rubin (1949) and Stock-Wright (2000) tests reject the null hypothesis (at the 1\% level) that the coefficients of the excluded instruments are jointly equal to zero. This indicates that the excluded instruments are statistically significant.

\subsection{Excluding Regions}

In Table 12 in the Appendix we study whether our main results are sensitive to excluding regions. Sequentially, we drop countries in Asia (columns (1)-(3)), Africa (columns (4)-(6)), the Americas (columns (7)-(9)), Europe (columns (10)-(12)), and Oceania (columns (13)-(15)). The main results remain consistent overall. However, while the interactions of interest remain significant with consistent signs when we exclude the African continent, the direct effect of Stringency is positive. ${ }^{7}$

7 This may be a topic for future research. 
Table 8 Instrumental variable estimates

\begin{tabular}{|c|c|c|c|c|}
\hline & (1) & (2) & (3) & (4) \\
\hline Dep. Var. $=$ AOD & \multicolumn{2}{|c|}{$\mathrm{IV}=\mathrm{COVID}-19$ cases $(t-1)$} & \multicolumn{2}{|c|}{$\mathrm{IV}=\mathrm{COVID}-19$ cases $(t-5)$} \\
\hline \multicolumn{5}{|l|}{ Panel (a) } \\
\hline Stringency & $\begin{array}{l}-0.066 \\
(0.072)\end{array}$ & $\begin{array}{l}0.097 \\
(0.073)\end{array}$ & $\begin{array}{l}-0.028 \\
(0.075)\end{array}$ & $\begin{array}{l}0.140^{*} \\
(0.076)\end{array}$ \\
\hline Proportional $\times$ Stringency & $\begin{array}{l}0.072^{* * *} \\
(0.009)\end{array}$ & & $\begin{array}{l}0.072^{* * *} \\
(0.010)\end{array}$ & \\
\hline Majoritarian $\times$ Stringency & & $\begin{array}{l}-0.139^{* * *} \\
(0.011)\end{array}$ & & $\begin{array}{l}-0.142^{\text {*** }} \\
(0.011)\end{array}$ \\
\hline Stringency $\times$ Democracy & $\begin{array}{l}-0.008^{* * *} \\
(0.002)\end{array}$ & $\begin{array}{l}-0.010^{* * *} \\
(0.002)\end{array}$ & $\begin{array}{l}-0.007^{* * *} \\
(0.002)\end{array}$ & $\begin{array}{l}-0.009^{* * *} \\
(0.002)\end{array}$ \\
\hline Baseline controls & Yes & Yes & Yes & Yes \\
\hline Time dummies & Yes & Yes & Yes & Yes \\
\hline R-squared & 0.037 & 0.039 & 0.035 & 0.036 \\
\hline Observations & 21,236 & 21,236 & 20,760 & 20,760 \\
\hline \multicolumn{5}{|l|}{ Diagnostic tests } \\
\hline Cragg-Donald Wald F statistic & $\begin{array}{l}574.64 \\
{[5 \% \text { c.v. }=20.25]}\end{array}$ & $\begin{array}{l}574.10 \\
{[5 \% \text { c.v. }=20.25]}\end{array}$ & $\begin{array}{l}540.99 \\
{[5 \% \text { c.v. }=20.25]}\end{array}$ & $\begin{array}{l}542.24 \\
{[5 \% \text { c.v. }=20.25]}\end{array}$ \\
\hline Anderson-Rubin Wald test & $\begin{array}{l}260.68 \\
{[p=0.000]}\end{array}$ & $382.75[p=0.000]$ & $\begin{array}{l}253.68 \\
{[p=0.000]}\end{array}$ & $\begin{array}{l}370.65 \\
{[p=0.000]}\end{array}$ \\
\hline Stock-Wright LM S statistic & $\begin{array}{l}257.52 \\
{[p=0.000]}\end{array}$ & $\begin{array}{l}375.98 \\
{[p=0.000]}\end{array}$ & $\begin{array}{l}250.61 \\
{[p=0.000]}\end{array}$ & $\begin{array}{l}364.15 \\
{[p=0.000]}\end{array}$ \\
\hline & (1) & (2) & (3) & \\
\hline Dep. Var. $=$ AOD & $\mathrm{IV}=$ Irrigation po & tential & & \\
\hline \multicolumn{5}{|l|}{ Panel (b) } \\
\hline Stringency & $\begin{array}{l}-0.268^{* * * *} \\
(0.058)\end{array}$ & $\begin{array}{l}-0.125^{* *} \\
(0.061)\end{array}$ & $\begin{array}{l}-0.033 \\
(0.063)\end{array}$ & \\
\hline Proportional $\times$ Stringency & & $\begin{array}{l}0.099^{* * * *} \\
(0.010)\end{array}$ & & \\
\hline Majoritarian $\times$ Stringency & & & $\begin{array}{l}-0.126^{* * * *} \\
(0.011)\end{array}$ & \\
\hline Stringency $\times$ Democracy & $\begin{array}{l}-0.016^{* * * *} \\
(0.003)\end{array}$ & $\begin{array}{l}-0.024^{* * *} \\
(0.003)\end{array}$ & $\begin{array}{l}-0.022^{* * * *} \\
(0.003)\end{array}$ & \\
\hline Baseline controls & Yes & Yes & Yes & \\
\hline Time dummies & Yes & Yes & Yes & \\
\hline R-squared & 0.036 & 0.037 & 0.042 & \\
\hline Observations & 21,176 & 21,176 & 21,176 & \\
\hline \multicolumn{5}{|l|}{ Diagnostic tests } \\
\hline Cragg-Donald Wald F statistic & $\begin{array}{l}4913.78 \\
{[5 \% \text { c.v. }=20.25]}\end{array}$ & $\begin{array}{l}4296.18 \\
{[5 \% \text { c.v. }=20.25]}\end{array}$ & $\begin{array}{l}4806.47 \\
{[5 \% \text { c.v. }=20.25]}\end{array}$ & \\
\hline Anderson-Rubin Wald test & $\begin{array}{l}41.97 \\
{[p=0.000]}\end{array}$ & $\begin{array}{l}66.86 \\
{[p=0.000]}\end{array}$ & $\begin{array}{l}52.71 \\
{[p=0.000]}\end{array}$ & \\
\hline Stock-Wright LM S statistic & $\begin{array}{l}41.88 \\
{[p=0.000]}\end{array}$ & $\begin{array}{l}66.65 \\
{[p=0.000]}\end{array}$ & $\begin{array}{l}52.58 \\
{[p=0.000]}\end{array}$ & \\
\hline
\end{tabular}

See Table 1 


\section{Conclusion}

In this paper, we test the hypothesis that the effect of COVID-19 regulations on air pollution is conditional on the level of democracy and on electoral rules. By controlling for the level of confidence in government, trust in politicians, and social capital, we seek to understand whether any rally-around-the-flag effects occurred. We find that a given COVID-19 policy stringency yielded improvements in air quality roughly $57 \%$ greater in majoritarian systems than in proportional systems. Mobility effects help explain this pattern.

During the crisis, majoritarian systems appear to have experienced rally-around-the-flag effects, encouraging adherence with COVID-19 regulations to a greater degree than in proportional systems. Confidence in government, trust in politicians and social capital also impact the regulatory effects on mobility and air quality.

\section{Appendix}

See Tables 9, 10, 11, 12. 


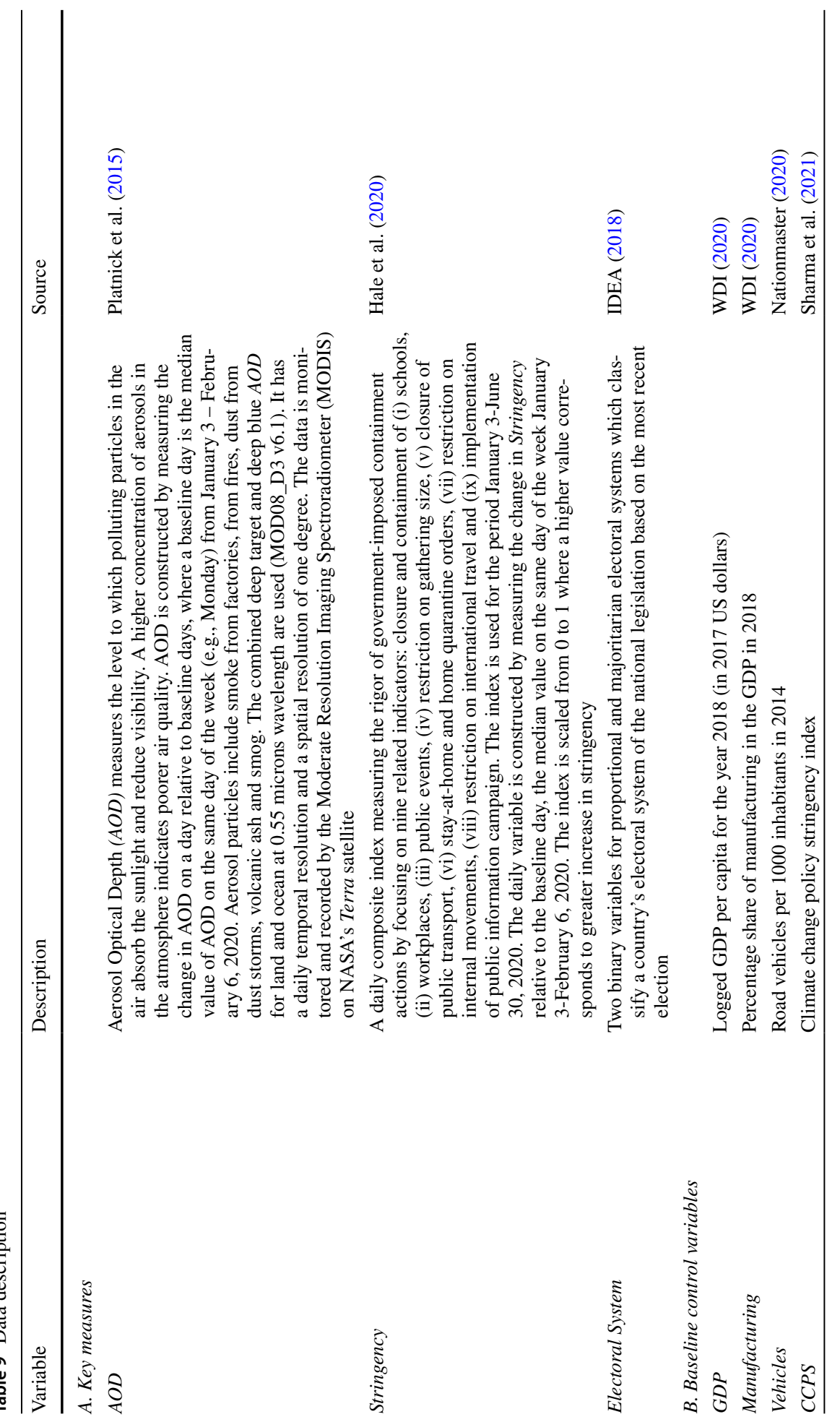




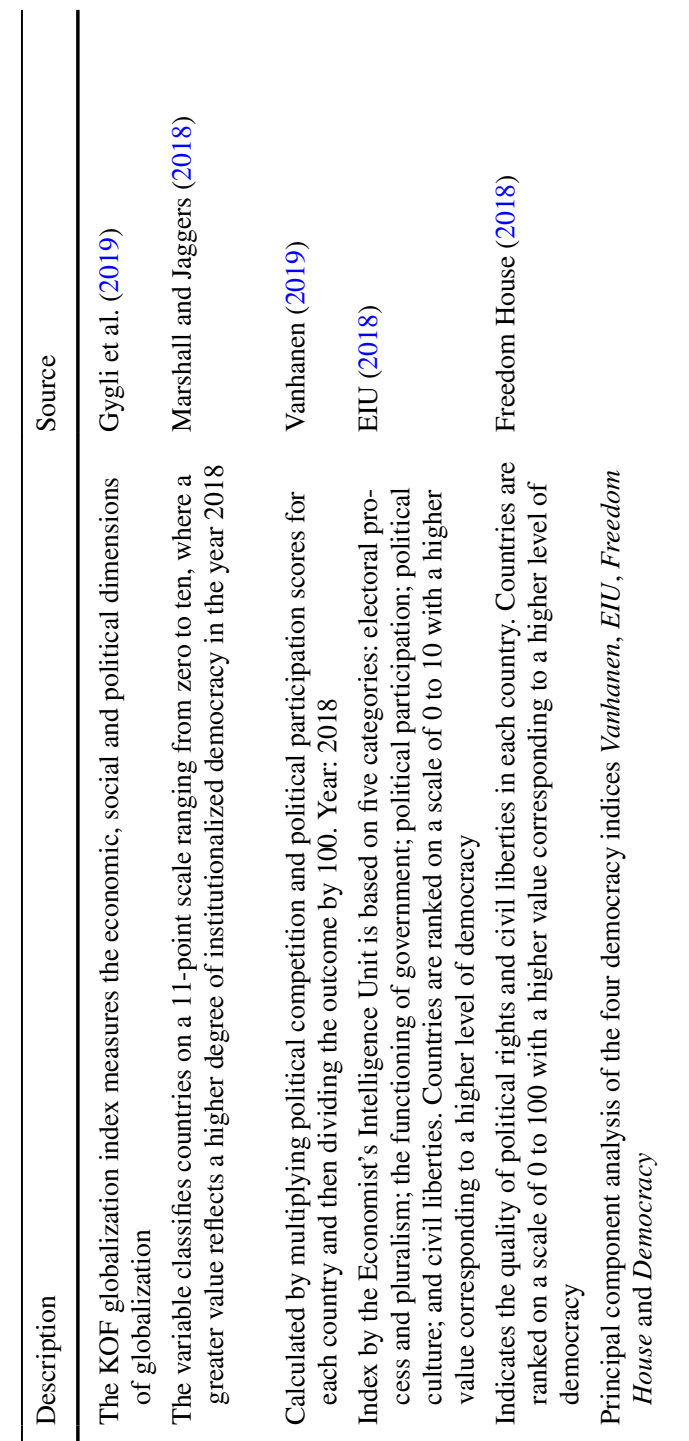

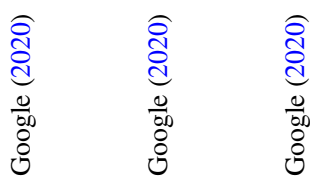

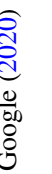

节

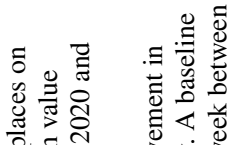

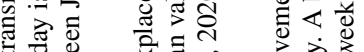

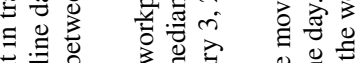

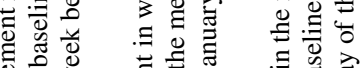

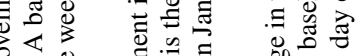

突志

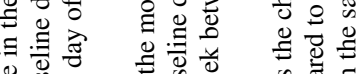

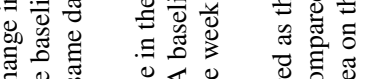

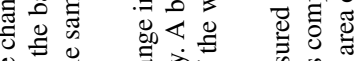

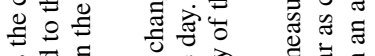

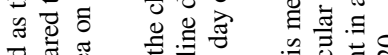

总芯芯

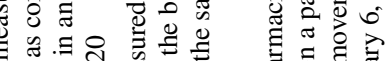

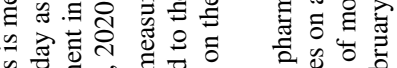
जै छ

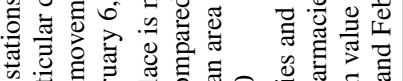

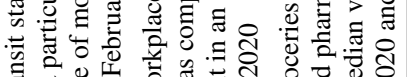

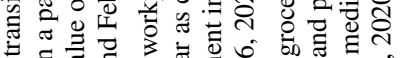
ప ह त

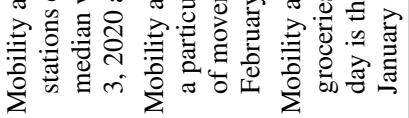

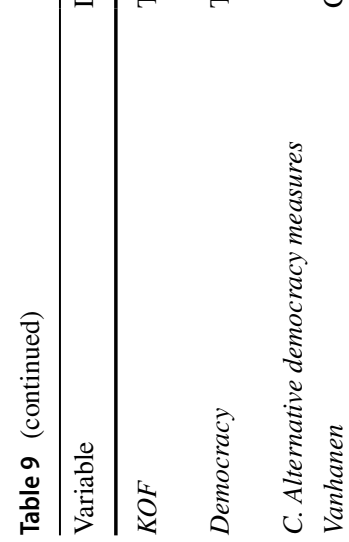

?
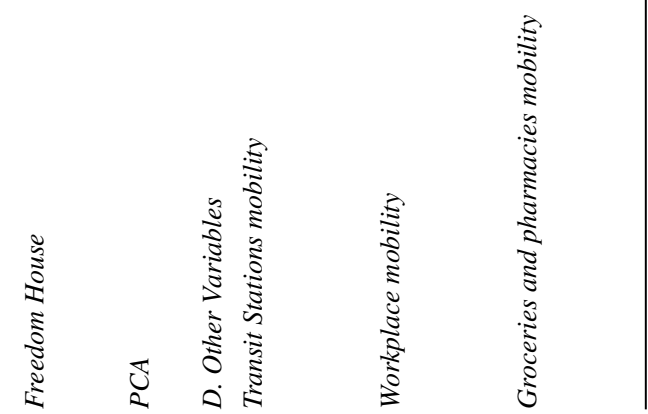


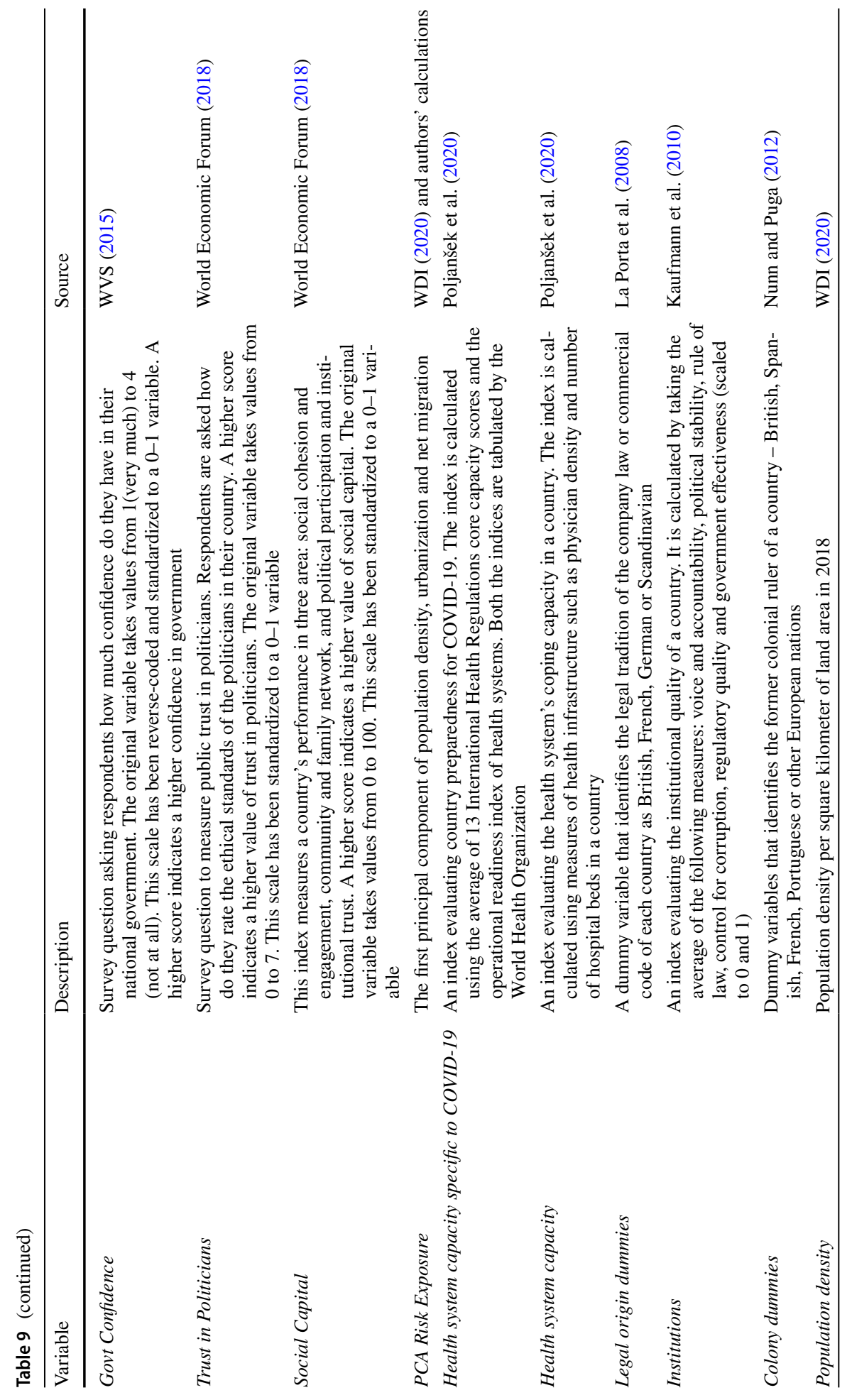




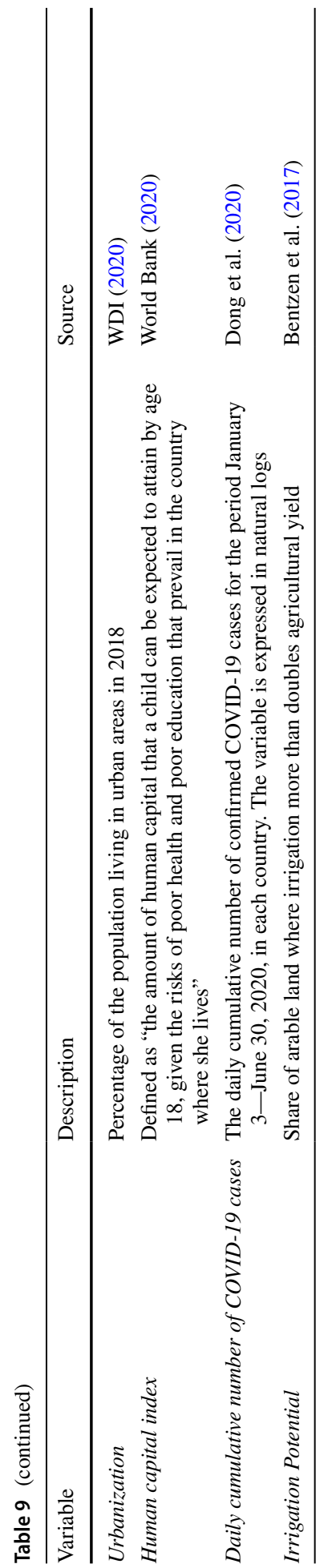


Table 10 Summary statistics

\begin{tabular}{llrrll}
\hline Variable & Observations & \multicolumn{1}{c}{ Mean } & Std. Deviation & Minimum & Maximum \\
\hline AOD & 21,355 & 0.049 & 0.209 & -0.828 & 3.998 \\
Stringency & 21,355 & 0.440 & 0.357 & -0.449 & 1 \\
Proportional & 21,355 & 0.453 & 0.499 & 0 & 1 \\
Majoritarian & 21,355 & 0.311 & 0.463 & 0 & 1 \\
Democracy & 21,355 & 6.311 & 3.569 & 0 & 10 \\
CCPS & 21,355 & 0.332 & 0.175 & 0.013 & 0.862 \\
Manufacturing & 21,355 & 12.894 & 6.281 & 1.748 & 38.201 \\
Vehicles & 21,355 & 213.288 & 221.669 & 3.000 & 797.000 \\
GDP & 21,355 & 9.373 & 1.149 & 6.766 & 11.332 \\
KOF & 21,355 & 66.550 & 13.873 & 38.162 & 91.277 \\
Govt Confidence & 12,920 & 0.364 & 0.104 & 0.194 & 0.691 \\
Trust in Politicians & 19,034 & 0.322 & 0.119 & 0.133 & 0.623 \\
Social Capital & 19,043 & 0.514 & 0.068 & 0.385 & 0.669 \\
Transit Stations & 17,559 & -25.529 & 28.445 & -95 & 31 \\
Workplace & 17,559 & -17.955 & 24.280 & -92 & 43 \\
Groceries \& pharmacies & 17,559 & -10.857 & 20.666 & -97 & 76 \\
Average mobility & 17,559 & -18.114 & 23.077 & -93.333 & 36.667 \\
\hline
\end{tabular}

Stringency declined in some locations compared to the baseline period, resulting in negative values

Table 11 Summary Statistics by Political Institution

\begin{tabular}{lcllll}
\hline Variable & Observations & Mean & Std. Deviation & Minimum & Maximum \\
\hline \multicolumn{2}{l}{ Proportional systems } & & & & \\
AOD & 9641 & 0.057 & 0.198 & -0.828 & 3.242 \\
Stringency & 9641 & 0.443 & 0.364 & -0.111 & 1 \\
Democracy & 9641 & 7.603 & 2.838 & 0 & 10 \\
Majoritarian systems & 6627 & & & & 3.998 \\
AOD & 6627 & 0.031 & 0.246 & -0.824 & 1 \\
Stringency & 6627 & 0.420 & 0.344 & -0.111 & 10 \\
Democracy & & 4.696 & 3.670 & 0.000 & 2.337 \\
Autocracies & 4630 & & & -0.718 & 1 \\
AOD & 4630 & 0.072 & 0.243 & -0.449 & 2 \\
Stringency & 4630 & 0.449 & 0.372 & 0 & \\
Democracy & 0.386 & 0.625 & & 1 \\
\hline
\end{tabular}

Stringency declined in some locations compared to the baseline period, resulting in negative values 


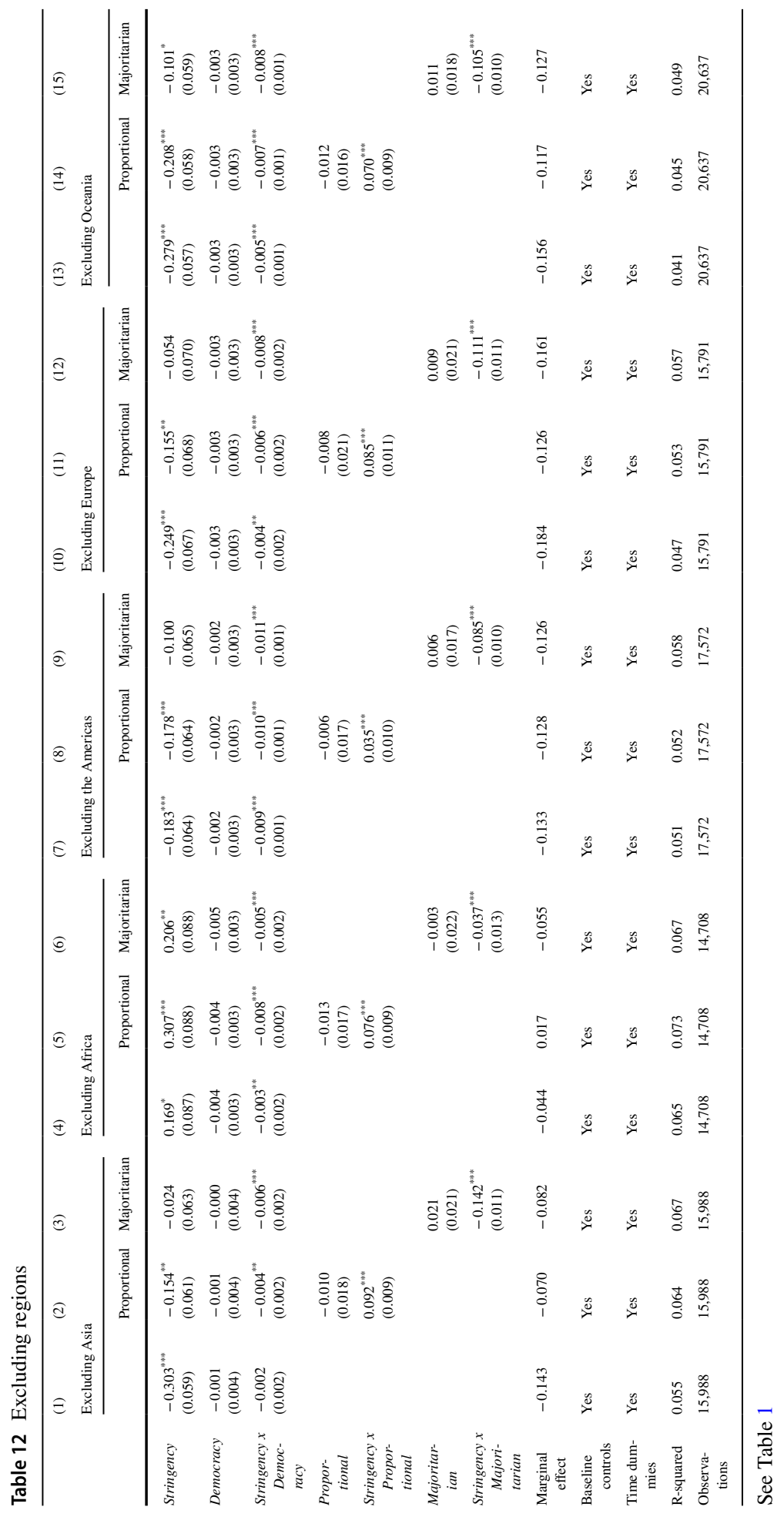


Acknowledgements The authors thank the three insightful referees, James Ang, Cooper Day, Jose Fernandez and Cheng Keat Tang for useful comments and suggestions, the co-editor Grischa Perino for helpful guidance and suggestions, and Catherine Lewis for research assistance. The usual disclaimers apply.

\section{References}

IDEA (2018) Electoral system design database. International Institute for Democracy and Electoral Assistance, Accessed at: https://www.idea.int/data-tools/data/electoral-system-design

Abadie A, Athey S, Imbens S, Wooldridge J (2017) 'When should you adjust standard errors for clustering?', NBER Working Paper No. 24003

Acemoglu D, Naidu S, Restrepo P, Robinson JA (2019) Democracy does cause growth. J Polit Econ 127(1):47-100

Anderson TW, Rubin H (1949) Estimation of the parameters of a single equation in a complete system of stochastic equations. Ann Math Stat pp 46-63

Ang JB, Fredriksson PG (2021) Does an early start help or hurt? Statehood, institutions and modern climate change policies. Energy Econ 94:105075

Bentzen JS, Kaarsen N, Wingender AM (2017) Irrigation and autocracy. J Eur Econ Assoc 15(1):1-53

Blair RA, Morse BS, Tsai LL (2017) Public health and public trust: survey evidence from the Ebola virus disease epidemic in Liberia. Soc Sci Med 172:89-97

Bol D, Giani M, Blais A, Loewen PJ (2021) The effect of COVID-19 lockdowns on political support: Some good news for democracy? Eur J Polit Res 60(2):497-505

Brodeur A, Cook N, Wright T (2021) On the effects of COVID-19 safer-at-home policies on social distancing, car crashes and pollution. J Environ Econ Manag 106:102427

Chu DA (2006) 'Analysis of the relationship between MODIS aerosol optical depth and PM2.5 in the summertime US', Remote Sensing of Aerosol and Chemical Gases, Model Simulation/Assimilation, and Applications to Air Quality 6299:629903

Clinton J, Cohen J, Lapinski J, Trussler M (2021) Partisan pandemic: How partisanship and public health concerns affect individuals' social mobility during COVID-19. Sci Adv 7(2):eabd7204

Cole MA, Elliott RJR, Liu B (2020) The impact of the wuhan covid-19 lockdown on air pollution and health: a machine learning and augmented synthetic control approach. Environ Resource Econ 76:553-580

Cragg JG, Donald SG (1993) Testing identifiability and specification in instrumental variable models. Econ Theory 9(2):222-240

Dang H-AH, Trinh T-A (2021) Does the COVID-19 lockdown improve global air quality? New crossnational evidence on its unintended consequences. J Environ Econ Manag 105:102401

Dinesen PT, Jæger MM (2013) The effect of terror on institutional trust: New evidence from the 3/11 Madrid Terrorist attack. Polit Psychol 34(6):917-926

Dong E, Du H, Gardner L (2020) An interactive web-based dashboard to track COVID-19 in real time. Lancet Infectious Diseases 20:533-534

Earle TC (2009) Trust, confidence, and the 2008 global financial crisis. Risk Anal 29(6):785-792

Eichengreen B, Aksoy CG, Saka O (2021) Revenge of the experts: will COVID-19 renew or diminish public trust in science? J Publ Econ 193:104343

EIU (2018) Democracy Index 2018. The Economist Intelligence Unit

Engel-Cox JA, Holloman CH, Coutant BW, Hoff RM (2004) Qualitative and quantitative evaluation of MODIS satellite sensor data for regional and urban scale air quality. Atmos Environ 38:2495-2509

Esaiasson P, Sohlberg J, Ghersetti M (2021) How the coronavirus crisis affects citizen trust in institutions and in unknown others: Evidence from 'the Swedish experiment.' Eur J Polit Res 60(3):748-760

Flückiger M, Ludwig M, Önder AS (2019) Ebola and state legitimacy. Econ J 129(621):2064-2089

Folke O (2014) Shades of brown and green: party effects in proportional election systems. J Eur Econ Assoc 12(5):1361-1395

Fredriksson PG, Wollscheid JR (2015) Legal origins and climate change policies in former colonies. Environ Resource Econ 62(2):309-327

Google (2020) 'COVID-19 Community Mobility Reports'. Accessed at: https://www.google.com/covid 19/mobility/

Groeniger JO, Noordzij K, van der Waal J, de Koster W (2021) Dutch COVID-19 lockdown measures increased trust in government and trust in science: a difference-in-differences analysis. Soc Sci Med 275:113819 
Guglielmi S, Dotti Sani GM, Molteni F et al (2020) Public acceptability of containment measures during the COVID-19 pandemic in Italy: how institutional confidence and specific political support matter. Int J Sociol Soc Policy 40(9/10):1069-1085

Gupta P, Christopher SA, Wang J, Gehrig R, Lee Y, Kumar N (2006) Satellite remote sensing of particulate matter and air quality assessment over global cities. Atmos Environ 40:5880-5892

Gutierrez E (2010) Using satellite imagery to measure the relationship between air quality and infant mortality: an empirical study for Mexico. Popul Environ 31:203-222

Gygli S, Haelg F, Potrafke N, Sturm J-E (2019) The KOF globalisation index - revisited. Rev Int Organ 14:543-574

Hale T, Webster S, Petherick A, Phillips T, Kira B (2020) Oxford COVID-19 government response tracker. Oxford University, Blavatnik School of Government

Helm D (2020) The environmental impacts of the coronavirus. Environ Resource Econ 76:21-38

Hetherington MJ, Nelson M (2003) Anatomy of a rally effect: George W. Bush and the war on terrorism. PS Polit Sci Polit 36(1):37-42

Freedom House (2018) 'Freedom in the World 2018'. Accessed at: https://freedomhouse.org

$\mathrm{Hu}$ H, Chen D (2021) The political economy of environmental consequences: a review of the empirical literature. J Econ Surv 35(1):250-306

Hu Z, Rao KR (2009) Particulate air pollution and chronic ischemic heart disease in the eastern united states: a county level ecological study using satellite aerosol data. Environ Health 8:26

Hutchison KD (2003) Applications of MODIS satellite data and products for monitoring air quality in the state of Texas. Atmos Environ 37:2403-2412

IPCC (2013) Working Group I Contribution to the IPCC Fifth Assessment Report (AR5) Climate Change 2013: The Physical Science Basis (Geneva, Switzerland: Intergovernmental Panel on Climate Change)

Kammerlander A, Schulze GG (2020) Are democracies cleaner? Eur J Polit Econ 64:101920

Kaufmann D, Kray A, Mastruzzi M (2010) The worldwide governance indicators: methodology and analytical issues. Policy Research Working Paper 5430, The World Bank

Khoshsima M, Ahmadi-Givi F, Bidokhti A, Sabetghadam S (2014) Impact of meteorological parameters on relation between aerosol optical indices and air pollution in a sub-urban area. J Aerosol Sci 68:46-57

Kong L, Xin J, Zhang W, Wang Y (2016) The empirical correlations between PM2.5, PM10 and AOD in the Beijing metropolitan region and the PM2.5, PM10 distributions retrieved by MODIS. Environ Pollut 216:350-360

La Porta R, Lopez-de-Silanes F, Shleifer A (2008) The economic consequences of legal origins. J Econ Lit 46(2):285-332

Lee K (2021) Pandemics, mitigation measures, and environment. Environ Resource Econ 78:353-374

Li L, Li Q, Huang L et al (2020) Air quality changes during the COVID-19 lockdown over the Yangtze River Delta Region: An insight into the impact of human activity pattern changes on air pollution variation. Sci Total Environ 732(25):139282

Li Z, Xia X, Cribb M, Mi W, Holben B, Wang P, Chen H, Tsay S-C, Eck TF, Zhao F, Dutton EG, Dickerson RE (2007) Aerosol optical properties and their radiative effects in Northern China. J Geophys Res Atmos 112

Liu S, Kong G, Kong D (2020) Effects of the COVID-19 on air quality: human mobility, spillover effects, and city connections. Environ Resource Econ 76:635-653

Marien S, Hooghe MM (2011) Does political trust matter? An empirical investigation into the relation between political trust and support for law compliance. Eur J Polit Res 50:267-291

Marshall MG, Jaggers K (2018) Polity V Project. Center for International Development and Conflict Management, University of Maryland

Nationmaster (2020) 'Motor vehicles per 1000 people', Accessed at: https://www.nationmaster.com

NOAA (2020) 'Global Monitoring Laboratory. SURFRAD Aerosol Optical Depth'. Retrieved on: 6 Jun 2020. Accessed at: https://www.esrl.noaa.gov/gmd/grad/surfrad/aod/

Noy I, Doan B, Ferrarini B, Park D (2020) 'Measuring the economic risk of Covid-19', Covid Econ 3

Nunn N, Puga D (2012) Ruggedness: the blessing of bad geography in Africa. Rev Econ Stat 94:20-36

Platnick S, Hubanks P, Meyer K, King MD (2015) 'TERRA/MODIS Atmosphere L3 Monthly Product (08_ L3)'. NASA MODIS Adaptive Processing System, Goddard Space Flight Center, USA, Accessed at: https://giovanni.gsfc.nasa.gov

Poljanšek K, Marin-Ferrer M, Vernaccini L, Messina L (2020) Incorporating epidemics risk in the INFORM Global Risk Index, EUR 29603 EN (Luxembourg: Publications Office of the European Union)

Sagarzazu I, Kluver H (2017) Coalition governments and party competition: political communication strategies of coalition parties. Polit Sci Res Methods 5(2):333-349 
Saha S, Su JJ, Campbell N (2017) Does political and economic freedom matter for inbound tourism? A cross-country panel data estimation. J Travel Res 56(2):221-234

Schraff D (2021) Political trust during the Covid-19 pandemic: Rally around the flag or lockdown effects? Eur J Polit Res 60(4):1007-1017

Shapiro JS, Walker R (2018) Why is pollution from US manufacturing declining? The roles of environmental regulation, productivity, and trade. Am Econ Rev 108(12):3814-3854

Sharma S, Zhang M et al (2020) Effect of restricted emissions during COVID-19 on air quality in India. Sci Total Environ 732(25):138878

Sharma S, Ang JB, Fredriksson PG (2021) Religiosity and climate change policies. Energy Econ 101:105414

Shi Y, Ho HC, Xu Y, Ng E (2018) Improving satellite aerosol optical depth-PM2.5 correlations using land use regression with microscale geographic predictors in a high-density urban context. Atmos Environ 190:23-34

Skali A, Stadelmann D, Torgler B (2021) Trust in government in times of crisis: a quasi-experiment during the two world wars. J Comp Econ 49(2):277-289

Stock JH, Wright JH (2000) GMM with Weak Identification. Econometrica 68:1055-1096

Stock JH, Yogo M (2005) 'Testing for weak instruments in linear IV regression'. Identification and Inference for Econometric Models: Essays in Honor of Thomas Rothenberg. Cambridge University Press, Cambridge, pp 80-108

van Bavel JJ, Baicker K, Boggio PS et al (2020) Using social and behavioural science to support COVID-19 pandemic response. Nat Hum Behav 4:460-471

Vanhanen T (2019) 'Measures of Democracy 1810-2018', Finnish social science data archive. Accessed at: https://services.fsd.uta.fi/catalogue/FSD1289

Wang Z (2021) Blame the foreigners? Exports and sulfur dioxide emissions in China. Environ Resour Econ 80:279-309

Ware A (2001) Electoral systems. In: Smelser NJ, Baltes PB (eds) International encyclopedia of the social and behavioral sciences. Pergamon, Oxford, pp 4378-4382

WDI (2020) World development indicators. World Bank, Philadelphia

Woelfert FS, Kunst JR (2020) How political and social trust can impact social distancing practices during COVID-19 in Unexpected Ways. Front Psychol 11:3552

World Bank (2020) The Human Capital Index (HCI) Database. World Bank, Washington

World Economic Forum (2018) Global Competitiveness Index Dataset 2017-2019. World Economic Forum, Geneva

WVS (2015) World Value Survey 1981-2014 Longitudinal Aggregate v.20150418, 2015. www.worldvalue ssurvey.org. (Madrid, Spain: World Values Survey Association).

Publisher's Note Springer Nature remains neutral with regard to jurisdictional claims in published maps and institutional affiliations. 